\title{
STUDI KESELARASAN PEMBELAJARAN CNC/CAM PADA LPTK, SMK, DAN INDUSTRI MENYONGSONG ERA REVOLUSI INDUSTRI 4.0 BIDANG MANUFAKTUR
}

\author{
Yuyun Estriyanto1), Valiant Lukad Perdana Sutrisno'), Taufik Wisnu Saputra' \\ 1,2,3 Program Studi Pendidikan Teknik Mesin, Fakultas Keguruan dan Ilmu Pendidikan, Universitas Sebelas Maret \\ Email: yuyun.e@staff.uns.ac.id, valiantlps@staff.uns.ac.id, taufikwisnusaputra@staff.uns.ac.id
}

\begin{abstract}
ABSTRAK
Dalam bidang manufaktur, pemesinan CNC/CAM merupakan teknologi pemesinan yang paling berpotensi untuk dikembangkan menyesuaikan dengan revolusi industri 4.0. Penelitian ini dilakukan untuk melihat tingkat keterlaksanaan pembelajaran $\mathrm{KI} / \mathrm{KD}$ CNC/CAM di SMK dan LPTK serta relevansinya terhadap kebutuhan industri. Penelitian dilaksanakan dengan triangulation mixed method design, yaitu desain penelitian campuran antara kualitatif dan kuantitatif yang dilaksanakan secara bersamaan. Penelitian kuantitatif dilaksanakan dengan desain survei menggunakan instrumen kuesioner yang hasilnya diolah dan disajikan secara deskriptif, sedangkan pendekatan kualitatif dilaksanakan dengan metode interview dan observasi partisipatif yang hasilnya disarikan dan diinterpretasikan untuk memperkuat temuan penelitian kuantitatif. Penelitian dilaksanakan pada SMK-SMK di Kota Surakarta yang menyelenggarakan Kompetensi Keahlian Teknik Pemesinan. Dari penelitian ini ditemukan bahwa berbagai $\mathrm{KI} / \mathrm{KD}$ dalam bidang CNC sebagaimana yang diamanatkan dalam kurikulum telah terlaksana dengan baik dalam pembelajaran di SMK maupun LPTK. Penelitian ini juga mengkonfirmasi bahwa KI/KD bidang CNC/CAM antara LPTK, SMK, dan industri, saat ini pada level 'sangat relevan'. Penelitian juga menemukan bahwa jenis mesin, controller, dan software CAM bukan lah suatu permasalahan dalam link-and-match pembelajaran CNC/CAM, akan tetapi, yang menjadi kunci keselarasan adalah KI/KD pembelajaran. Dalam penelitian ini juga terungkap bahwa LPTK dan SMK cenderung konsisten menyampaikan KI/KD sesuai amanat kurikulum, sedangkan industri memiliki kecenderungan ada $\mathrm{KI} / \mathrm{KD}$ tertentu yang lebih dominan dibanding dengan $\mathrm{KI} / \mathrm{KD}$ yang lain.
\end{abstract}

Kata kunci: CNC, CAM, SMK, relevansi, link-and-match, LPTK

\begin{abstract}
CNC/CAM technology could be the most potential machining technology that can be developed following the 4.0 industrial revolution. This research aims to study the level of compliance of CNC/CAM competency (KI/KD) in Vocational High School (VHS) and Vocational Teacher Education (VTE) institution and its relevance to the industrial skill needs. The research was conducted with a mixed-method triangulation design, a mixed research design between qualitative and quantitative approaches, carried out simultaneously. The quantitative approach was performed with a survey design using a questionnaire whose results were processed and presented descriptively. The qualitative approach is carried out through interviews and participatory observation. The results are summarized and interpreted to strengthen the conclusions of the quantitative finding. The research was conducted at VHSes in the city of Surakarta which held the Mechanical Engineering Competency. The study shows that various competencies in CNC Machining as mandated by the curriculum have been well carried out at VHS and VTE. This study also confirms that the CNC/CAM competencies in the VTE institution, VHSes, and the industry is currently at a highrelevant level. The research also finds that the type of machine, controller, and CAM software is not a problem in CNC/CAM learning conformity, however, the key to alignment was the learning competencies. Furthere more, it also reveals that VTE and VHS tend to consistently deliver KI/KD as mandated by the curriculum, while the industries tend to have certain KI/KD which tend to be more dominant than the others.
\end{abstract}

Keywords : CNC, CAM, VHS, conformity, VTE 


\section{PENDAHULUAN}

Pendidikan kejuruan adalah pendidikan penyiapan tenaga kerja, oleh karena itu pendidikan kejuruan berhubungan erat dengan dunia industri. Lembaga pendidikan kejuruan berperan sebagai penghasil tenaga kerja, sedangkan industri merupakan pihak yang akan mempekerjakan lulusan yang dihasilkan oleh lembaga pendidikan kejuruan. Oleh karena itu harus terjalin keselarasan (link-andmatch) antara kedua lembaga tersebut [1]. Dalam hal ini keselarasan dimaknai sebagai sesuaian antara antara sisi permintaan (demand) pada dunia industri dengan sisi penyedia (supply) tenaga kerja oleh lembaga pendidikan kejuruan. Keselarasan tersebut meliputi keselarasan pada aspek kualitas, kuantitas, lokasi, dan waktu [2]. Lemahnya link-and-match antara pendidikan kejuruan dengan dunia kerja menyebabkan terjadinya pengangguran yang akan menyebabkan lemahnya daya saing perekonomian bangsa. Billet [3] menekankan perlunya rekonsiliasi semua pihak yang terkait dengan penyedia dan pengguna tenaga kerja untuk membahas bersama kurikulum pendidikan tenaga kerja sehingga keperluan pada sisi supply dan demand bisa ketemu.

Dalam sistem pendidikan nasional terdapat dua istilah yang bermakna sama. Istilah pendidikan kejuruan berasosiasi pada pendidikan siap kerja pada jenjang pendidikan menengah (SMK), sedangkan pendidikan vokasi berasosiasi kepada pendidikan siap kerja pada jenjang pendidikan tinggi (jalur diploma) [4]. Dalam literasi global, kedua istilah tersebut sama-sama dikenal dengan istilah vocational education. Oleh karena itu pada dasarnya paradigma-paradigma pembelajaran yang berlaku di SMK maupun pendidikan vokasi adalah sama. Pembelajaran di SMK maupun jenjang diploma harus mengacu pada dunia kerja di industri.

Perkembangan dunia industri yang sangat cepat telah membawa dunia pada era revolusi industri 4.0 [5]. Istilah ini mengacu pada era dimana terjadi transformasi yang sangat dinamis bagaimana berbagai aspek bisnis dan produksi berlangsung. Gelombang baru teknologi global akan mengubah produksi global. Internasionalisasi dalam semua aspek bisnis dan industri, akan menjadi keharusan. Negara-negara tidak lagi dapat terkurung dalam perbatasannya tetapi harus menjadi warga dunia. Lembaga pendidikan harus mampu berperan menyiapkan generasi-generasi yang mampu menjadi bagian peradaban baru, hidup dengan kultur sosial yang baru dan bertahan secara ekonomi dalam lingkungan ekonomi baru. Digitalisasi pada semua aspek kehidupan akan menghilangkan banyak pekerjaan [6] sehingga generasi yang akan datang harus disiapkan untuk memiliki agilitas terhadap dinamika dunia kerja di masa yang akan datang.

Revolusi industri 4.0 ditandai dengan pengoperasian teknologi otomasi, pertukaran data yang sangat cepat, penggalian data otomatis sehingga tercipta basis data masiv yang dapat dipergunakan untuk pengambilan keputusan secara otomatis (big data) dan menggerakkan sistem fisik-maya (physical cyber system), komputasi awan (cloud computing), robotika, kendaraan tanpa awak (autonomous vehicle), virtual-augmented reality, dan internetisasi berbagai hal (internet of things, IoT) [7]. Kondisi ini akan mempengaruhi kinerja pendidikan vokasi yang menyiapkan lulusannya untuk bekerja, khususnya dalam hal pengembangan kurikulum, penyesuaian perangkat pembelajaran dan kesiapan berubah para pendidiknya [8]. Mau tidak mau, pembelajaran kejuruan, khususnya bidang teknik pemesinan, juga harus menuju ke arah sana.

Bidang manufaktur merupakan salah bidang pekerjaan yang sangat tua, sejak zaman prasejarah hingga era revolusi industri. Bidang ini tidak akan pernah hilang dari peradaban, akan tetapi harus bisa menemukan segmen yang tepat, sejalan dengan revolusi industri. Sebagai contoh, pergeseran teknologi mobil dari mesin pembakaran internal menjadi kendaraan elektrik akan memangkas jumlah komponen dari 2000 komponen menjadi hanya beberapa komponen saja dan ini akan menghilangkan banyak pekerjaan karena hilangnya supplay chain [9]. Hal ini tentu akan berimplikasi pada hilangnya industri manufaktur komponen yang tidak lagi dibutuhkan tersebut. Jika hal ini hanya dimaknai sampai di situ, maka dunia manufaktur harus bersiap menjadi korban era disrupsi. Dalam hal ini, pelaku dunia manufaktur harus menyesuaikan bisnis manufakturnya untuk mensupport produksi komponen-komponen mobil listrik.

Dalam bidang manufaktur, terobosan otomasi yang berpeluang untuk dikembangkan dalam era revolusi industri 4.0 di antaranya adalah pemesinan CNC yang memungkinkan diarahkan menuju pemesinan berbasis cloud [10]. Pemesinan CNC berpeluang untuk dibawa ke sistem cloud karena perkembangan teknologi mesin CNC yang saat ini sudah mulai dilengkapi dengan processor dan control unit yang makin hari semakin meningkat kapabilitasnya. Mesin CNC yang dilengkapi dengan nomor IP (internet protocol) memungkinkan adanya komunikasi data dengan jaringan internet secara langsung. Oleh karena itu, pemesinan berbasis awan tinggal selangkah lagi. Jika bidang pemesinan tidak beranjak menyesuaikan diri secara digital maka akan menjadi bidang yang rentan terdisrupsi 
oleh revolusi industri 4.0 [6]. Bidang pemesinan pun bisa hilang pada masa yang akan datang, sesuai dengan prediksi publikasi dalam The Future of Jobs oleh Centre for the New Economy and Society [11].

Praksis pembelajaran pemesinan CNC di SMK ditentukan oleh beberapa hal. Mesin CNC yang dimiliki oleh SMK saat ini cukup beragam merk, kapasitas, dan kondisinya. Controller yang menyertai mesin-mesin tersebut juga beragam jenisnya sehingga ada beberapa hal yang berbeda dalam bahasa pemrogramannya. Demikian hanya perangkat lunak pemesinannya atau yang biasa disebut dengan Computer Aided Manufacturing (CAM). Untuk menjaga keselarasan dengan dunia industri, hubungan yang baik antara sekolah dengan industri sangat diperlukan. Sohimi [12] merekomendasikan sekolah kejuruan untuk lebih terbuka dan menyiapkan satu platform untuk mengakomodir masukan industri.

Apa pun jenis mesin, controller, dan perangkat lunak CAM-nya, kompetensi inti (KI) dan kompetensi dasar (KD) pembelajaran CNC di SMK diatur secara nasional melalui Peraturan Dirjen Dikdasmen No. 464/D.D5/KR/2018 [13] tentang Kompetensi Inti dan Kompetensi Dasar Mata Pelajaran SMK. Oleh karena itu, untuk melihat kesiapan SMK dalam menyongsong era pembelajaran revolusi industri 4.0 dalam bidang CNC perlu dipetakan daya dukung fasilitas (hardware dan software), keterlaksanaan standar pembelajaran CNC di SMK, serta tingkat relevansi kompetensi inti dan kompetensi dasar pembelajaran CNC di SMK dengan trend di dunia industri. Lebih jauh lagi, kesesuaian pengajaran CNC pada lembaga pencetak calon guru SMK juga perlu dilihat relevansinya dengan SMK maupun dunia industri. Penelitian ini dilaksanakan untuk tujuan tersebut. Untuk selanjutnya, penulisan Kompetensi Inti dan Kompetensi Dasar dalam artikel akan disingkat dengan $\mathrm{KI} / \mathrm{KD}$ karena merupakan istilah yang sangat umum dalam sistem kurikulum pendidikan nasional.

\section{METODE}

Sesuai dengan karakteristik rumusan masalah penelitian maka penelitian ini dilaksanakan dengan triangulation mixed method design. Triangulation mixed method adalah desain penelitian campuran antara kualitatif dan kuantitatif yang dilaksanakan secara bersamaan [14, p. 514]. Pengumpulan data kuantitatif dilaksanakan dengan teknik angket menggunakan instrumen berupa kuesioner. Pengumpulan data kuantitatif dilaksanakan dengan teknik pengumpulan data angket menggunakan instrumen berupa kuesioner tertutup dengan jenis pernyataan tertutup tiga atau lebih jawaban yang disediakan untuk responden yang kemudian diolah secara statistik untuk memperoleh tingkat relevansi pada kompetensi. Untuk mendapatkan data mengenai keterlaksanaan ini maka dipergunakan kuesioner tertutup yang disebarkan kepada Guru SMK mitra dan dosen pengampu mata kuliah CNC pada Prodi Pendidikan Teknik Mesin. Untuk mengetahui relevansi keterlaksanaan materi pembelajaran antara SMK terhadap Industri dan antara LPTK terhadap SMK dilakukan perhitungan persentase rerata skor masing-masing kompetensi. Persentase rerata skor dihitung dari jumlah skor aktual (skor yang diperoleh) dibagi dengan jumlah skor kriteria (skor maksimum) yang menjadi patokan relevansi [15].

$$
N P(\%)=\frac{R}{S M} \times 100 \%
$$

$$
\begin{array}{ll}
\mathrm{NP} & =\text { Nilai persentase } \\
\mathrm{R} & =\text { Skor yang diperoleh } \\
\mathrm{SM} & =\text { Skor maksimum. }
\end{array}
$$

Selanjutnya, dilakukan pengkategorian berdasarkan persentase yang didapatkan dengan menggunakan Kategori Persentase Keterlaksanaan Kompetensi pada sebagaimana pada Tabel 1.

Tabel 1. Kategori Persentase Keterlaksanaan Kompetensi

\begin{tabular}{cc}
\hline Taraf Presentase & Kategori \\
\hline $76 \%-100 \%$ & Sangat Relevan \\
\hline $56 \%-75 \%$ & Relevan \\
\hline $40 \%-55 \%$ & Kurang Relevan \\
\hline$<40 \%$ & Tidak Relevan \\
\hline
\end{tabular}

Untuk data kualitatif dilakukan dengan pertanyaan terbuka (bersamaan dengan kuesioner), serta indepth interview. Peneliti menyiapkan daftar topik wawancara tetapi tidak membatasi pada topik atau pertanyaan tersebut secara kaku. Sumber data dari penelitian ini didapatkan dengan menggali 
informasi melalui informan penelitian dan melakukan pengamatan terhadap fenomena yang terjadi di SMK yang berkaitan dengan implementasi standar pembelajaran CNC.

Penelitian ini dilaksanakan di seluruh SMK negeri dan swasta di Kota Surakarta Propinsi Jawa Tengah yang menyelenggarakan Kompetensi Keahlian Teknik Pemesinan. Peneliti mengacu pada Data Pokok online DITPSMK, yaitu http://datapokok.ditpsmk.net, dengan filtering lokasi Kota Surakarta, Bidang Keahlian Teknologi dan Rekayasa, Program Keahlian Teknik Mesin, Kompetensi Keahlian Teknik Pemesinan.

Objek penelitian ini adalah fasilitas pembelajaran CNC di SMK-SMK di Kota Surakarta, yang meliputi ketersediaan mesin, jenis controller yang dipergunakan, dan perangkat lunak CAM yang dipergunakan. Penelitian ini juga menyasar pada keterlaksanaan pembelajaran di lapangan saat ini. Keterlaksanaan $\mathrm{Kl} / \mathrm{KD}$ juga menjadi bagian yang dipelajari untuk melihat relevansi pembelajaran yang dilaksanakan di SMK dan Lembaga Pendidikan Tenaga Kependidikan (LPTK) guru kejuruan dan kebutuhan nyata oleh industri. Adapun yang dimaksud dengan LPTK dalam tulisan ini adalah Program Studi Pendidikan Teknik Mesin selaku lembaga penghasil guru SMK Teknik Pemesinan.

\section{HASIL DAN PEMBAHASAN}

\section{A. Daya Dukung Pembelajaran CNC/CAM SMK dan Keselarasannya dengan Dunia Industri}

Dari hasil observasi diketahui bahwa kondisi daya dukung pembelajaran CNC/CAM di SMKSMK di Kota Surakarta cukup beragam baik ketersediaan jenis mesin CNC, kecukupan jumlah, kondisi kesiapan beroperasi, jenis software CAM yang dipergunakan dalam pembelajaran dan jenis kontroler CNC. Kondisi ini tampak dipengaruhi oleh jenis sekolah (Negeri/Swasta) serta kemampuan yayasan dalam mensupport peralatan.

Informan dari industri CAD/CAM mengkonfirmasi bahwa dalam mengembangkan karyawan mereka hanya mempersyaratkan kemampuan dan keterampilan dasar saja, khususnya kemampuan membaca gambar dan matematika. Mereka tidak mempermasalahkan jenis software bahkan sertifikat yang dimiliki calon karyawan. Informan dari guru praktisi Lomba Kompetensi Siswa (LKS) SMK mengkonfirmasi bahwa pada dasarnya, lomba tidak mengacu ke salah satu jenis software, melainkan pada keterampilan siswa. Adapun jika ada keseragaman software yang dipergunakan dalam LKS, hal tersebut lebih disebabkan pada keluwesan sesuai kondisi existing di lapangan.

Dari konfirmasi informan yang berasal dari guru SMK dan pelaku industri terlihat bahwa linkand-match pada bidang pemesinan CNC/CAM tidak berasosiasi secara kaku pada jenis dan merk mesin CNC, controller CNC yang dipergunakan, serta jenis software CAM yang dipakai. Link-andmatch lebih mengacu pada $\mathrm{KI} / \mathrm{KD}$ pembelajaran yang memberikan pengetahuan dan keterampilan dasar yang menjadi modal dasar bagi lulusan untuk berkembang di dunia kerja.

\section{B. Keterlaksanaan KI/KD dalam Pembelajaran di SMK dan LPTK Kejuruan}

$\mathrm{KI} / \mathrm{KD}$ dalam pembelajaran CNC/CAM dalam penelitian ini mengacu pada $\mathrm{KI} / \mathrm{KD}$ Kurikulum SMK 2013 yang dikelompokkan menjadi: (1) pengetahuan umum mengenai CNC; (2) pengetahuan tentang mesin bubut CNC; (3) pengetahuan tentang mesin freis CNC; (4) keterampilan umum pemesinan CNC; (5) keterampilan pemesinan bubut CNC; dan (6) keterampilan pemesinan freis CNC. Kuesioner keterlaksanaan $\mathrm{KI} / \mathrm{KD}$ dibuat dalam skala Richter yang menunjukkan frekuensi KD tersebut disampaikan pada pembelajaran mulai dari 1 untuk Tidak Pernah, 2 untuk Jarang; 3 kadang-kadang, 4 untuk Sering, dan 5 untuk Sangat Sering. Rekap score keterlaksanaan KI/KD dalam pembelajaran di SMK dan LPTK disajikan pada Tabel 2.

Tabel 2. Keterlaksanaan KI/KD CNC/CAM dalam Pembelajaran di SMK dan LPTK

\begin{tabular}{lcc}
\hline \multicolumn{1}{c}{ Kelompok Kompetensi } & $\begin{array}{c}\text { Skor Keterlaksanaan } \\
\text { di SMK }\end{array}$ & $\begin{array}{c}\text { Skor Keterlaksanaan } \\
\text { di LPTK }\end{array}$ \\
\hline pengetahuan umum mengenai CNC & 3,74 & 3,56 \\
\hline $\begin{array}{l}\text { pengetahuan tentang mesin bubut } \\
\text { CNC }\end{array}$ & 3,72 & 3,98 \\
\hline $\begin{array}{l}\text { pengetahuan tentang mesin freis } \\
\text { CNC }\end{array}$ & 3,91 & 3,96 \\
\hline $\begin{array}{l}\text { keterampilan umum pemesinan } \\
\text { CNC }\end{array}$ & 3,88 & 3,75 \\
\hline keterampilan pemesinan bubut CNC & 3,72 & 4,04 \\
\hline keterampilan pemesinan freis CNC & 3,93 & 3,82 \\
\hline
\end{tabular}


Kompetensi umum bidang pengetahuan CNC diwakili dengan enam KD, yaitu: (1) memahami fungsi perintah untuk pembuatan program contour 2D dan 3D; (2) mengevaluasi program G Code; (3) memahami fungsi perintah memodifikasi G Code; (4) memahami fungsi perintah untuk proses drilling; (5) mengevaluasi program G Code; dan (6) memahami fungsi perintah memodifikasi G-Code. Hasil kuesioner menunjukkan bahwa secara keseluruhan, frekuensi keterlaksanaan pembelajaran seluruh KD di SMK adalah (score 3,74 dari skala 5) dan di LPTK (score 3,56 dari skala 5).

Kompetensi pengetahuan pemesinan bubut CNC diwakili dengan lima belas KD, yaitu: (1) memahami bagian-bagian mesin bubut CNC; (2) memilih parameter pemotongan mesin bubut CNC; (3) menerapkan teknik pemrograman mesin bubut CNC; (4) menerapkan prosedur pemesinan bubut CNC; (5) mengevaluasi kegagalan hasil pekerjaan mesin bubut CNC; (6) mengevaluasi prosedur pemesinan bubut CNC; (7) memahami CAM untuk proses bubut; (8) memahami jenis alat potong dan parameternya untuk CNC lathe; (9) memahami fungsi perintah untuk proses facing; (10) memahami fungsi perintah untuk proses roughing/finishing outer diameter; (11) memahami fungsi perintah untuk proses grooving outer diameter; (12) memahami fungsi perintah untuk proses roughing/finishing inner diameter; (13) memahami fungsi perintah untuk proses grooving inner diameter; (14) memahami fungsi perintah untuk proses pembuatan ulir luar dan dalam; dan (15) menganalisis program CAM lathe melalui proses simulasi. Hasil kuesioner menunjukkan bahwa secara keseluruhan, frekuensi keterlaksanaan pembelajaran seluruh KD pada kelompok kompetensi pengetahuan tentang mesin bubut CNC di SMK adalah (score 3,72 dari skala 5) dan di LPTK (score 3,98 dari skala 5).

Kompetensi pengetahuan pemesinan frais CNC diwakili dengan enam belas KD, yaitu: (1) memahami bagian- bagian mesin frais CNC; (2) memilih parameter pemotongan mesin frais CNC; (3) menerapkan teknik pemrograman mesin frais CNC; (4) menerapkan prosedur pemrograman mesin frais CNC; (5) mengevaluasi kegagalan hasil pekerjaan mesin frais CNC; (6) mengevaluasi prosedur pemesinan frais CNC; (7) menganalisis konsep dasar Computer Aided Manufacturing (CAM) untuk proses milling; (8) memahami jenis alat potong dan parameternya untuk CNC milling; (9) memahami fungsi perintah untuk membuat program drill toolpath; (10) memahami fungsi perintah membuat program facing and pocketing; (11) memahami fungsi perintah membuat program surface roughing and finishing; (12) menganalisis program CAM milling melalui proses simulasi; (13) memahami transfer G Code ke mesin CNC milling; (14) mengoperasikan program di mesin CNC milling; (15) memahami transfer G Code ke mesin CNC milling; dan (16) mengoperasikan program di mesin CNC milling. Hasil kuesioner menunjukkan bahwa secara keseluruhan, frekuensi keterlaksanaan pembelajaran seluruh KD pada kelompok kompetensi pengetahuan tentang mesin freis CNC di SMK adalah (score 3,91 dari skala 5) maupun di LPTK (score 3,96 dari skala 5).

Kompetensi umum keterampilan CNC diwakili empat KD, meliputi: (1) menggunakan program G Code; (2) menggunakan fungsi perintah memodifikasi G Code; (3) menggunakan program G Code; dan (4) menggunakan fungsi perintah memodifikasi $G$ Code. Hasil kuesioner menunjukkan bahwa secara keseluruhan, frekuensi keterlaksanaan pembelajaran seluruh KD pada kelompok kompetensi keterampilan umum pemesinan CNC di SMK adalah (score 3,88 dari skala 5) dan di LPTK (score 3,75 dari skala 5).

Kompetensi keterampilan mesin bubut CNC diwakili dengan enam belas KD, meliputi: (1) mengidentifikasi bagian-bagian mesin bubut CNC; (2) mengeset parameter pemotongan mesin bubut CNC; (3) melaksanakan pemrograman mesin bubut CNC; (4) membuat benda sederhana dengan mesin bubut CNC; (5) memperbaiki setting dan parameter lain pada pekerjaan pada mesin bubut CNC; (6) menggunakan teknik pemesinan bubut CNC; (7) menggunakan fungsi perintah-perintah dalam perangkat lunak CAM lathe; (8) mengidentifikasikan alat potong dan parameternya untuk CNC lathe; (9) menggunakan fungsi perintah dalam perangkat lunak CAM lathe untuk proses facing; (10) menggunakan fungsi perintah dalam perangkat lunak CAM lathe untuk proses drilling; (11) menggunakan fungsi perintah dalam perangkat lunak CAM lathe untuk proses roughing/finishing outer diameter; (12) menggunakan fungsi perintah dalam perangkat lunak CAM lathe untuk proses grooving outer diameter; (13) menggunakan fungsi perintah dalam perangkat lunak CAM lathe untuk proses roughing/finishing inner diameter; (14) menggunakan fungsi perintah dalam perangkat lunak CAM lathe untuk proses grooving inner diameter; (15) menggunakan fungsi perintah dalam perangkat lunak CAM lathe untuk proses pembuatan ulir luar dan dalam; serta (16) menentukan simulasi program CAM lathe. Hasil kuesioner menunjukkan bahwa secara keseluruhan, frekuensi keterlaksanaan pembelajaran seluruh KD pada kelompok kompetensi keterampilan pemesinan bubut CNC di SMK (score 3,72 dari skala 5) dan di LPTK (score 4,04 dari skala 5). 
Kompetensi keterampilan mesin freis CNC diwakili dengan tujuh belas KD, meliputi: (1) mengidentifikasi bagian-bagian mesin frais CNC; (2) mengeset parameter pemotongan mesin frais CNC; (3) melaksanakan pemrograman mesin frais CNC; (4) membuat benda sederhana dengan mesin frais CNC; (5) memperbaiki setting dan parameter lain pada pekerjaan pada mesin frais CNC; (6) menggunakan teknik pemesinan frais CNC; (7) mendemonstrasikan fungsi perintah-perintah dalam perangkat lunak CAM milling; (8) mengidentifikasi alat potong dan parameternya untuk CNC milling; (9) menggunakan perintah perangkat lunak CAM milling untuk program contour 2D dan 3D; (10) menggunakan fungsi perintah membuat program drill toolpath; (11) menggunakan fungsi perintah membuat program facing and pocketing; (12) menggunakan fungsi perintah membuat program surface roughing and finishing; (13) menentukan simulasi program CAM milling; (14) memindahkan G Code ke mesin CNC milling; (15) mengeksekusi program di mesin CNC milling; (16) mengelola transfer G Code ke mesin CNC milling; dan (17) menggunakan program di mesin CNC milling. Hasil kuesioner menunjukkan bahwa secara keseluruhan, frekuensi keterlaksanaan pembelajaran seluruh KD pada kelompok kompetensi keterampilan pemesinan freis CNC di SMK (score 3,93 dari skala 5) dan di LPTK (score 3,82 dari skala 5).

\section{Relevansi KI/KD Pembelajaran CNC di LPTK Kejuruan, SMK, dan Dunia Industri}

Survei relevansi materi pembelajaran mata pelajaran Teknik Pemesinan CNC di SMK dan LPTK dilaksanakan dengan membandingkan keterampilan yang dibutuhkan oleh industri pemesinan skala menengah ke atas pada pekerjaan pemesinan CNC setara operator. Diketahui terdapat 37 kompetensi pengetahuan dan 37 kompetensi keterampilan dasar yang terdapat pada kurikulum SMK. Untuk menganalisis tingkat relevansi kompetensi dilihat dari skor rata-rata frekuensi dilaksanakannya pembelajaran di SMK dan LPTK dengan persepsi seberapa relevan kompetensi yang diajarkan tersebut dengan kebutuhan industri.

Kuesioner untuk menilai tingkat relevansi KI/KD pembelajaran CNC/CAM di SMK, LPTK, dan dunia industri dibuat dalam skala Richter yang menunjukkan mulai dari 1 untuk Sangat Tidak Relevan, 2 untuk Tidak Relevan; 3 untuk Cukup Relevan, 4 untuk Relevan, dan 5 untuk Sangat Relevan. Rekap score relevansi pembelajaran CNC/CAM di SMK terhadap kebutuhan industri disajikan dalam Tabel 3 , sedangkan relevansi pembelajaran LPTK terhadap SMK disajikan pada Tabel 4.

Tabel 3. Relevansi KI/KD Pembelajaran SMK dengan Dunia Industri

\begin{tabular}{lcccc}
\hline \multicolumn{1}{c}{ Kelompok Kompetensi } & $\begin{array}{c}\text { Skor Rerata } \\
\text { SMK }\end{array}$ & $\begin{array}{c}\text { Skor Rerata } \\
\text { Industri }\end{array}$ & $\%$ & Kategori \\
\hline pengetahuan umum mengenai CNC & 3,74 & 4,33 & 86,37 & $\begin{array}{c}\text { Sangat } \\
\text { Relevan }\end{array}$ \\
\hline $\begin{array}{l}\text { pengetahuan tentang mesin bubut } \\
\text { CNC }\end{array}$ & 3,72 & 4,07 & 91,40 & $\begin{array}{c}\text { Sangat } \\
\text { Relevan }\end{array}$ \\
\hline $\begin{array}{l}\text { pengetahuan tentang mesin freis } \\
\text { CNC }\end{array}$ & 3,91 & 4,44 & 88,06 & $\begin{array}{c}\text { Sangat } \\
\text { Relevan }\end{array}$ \\
\hline keterampilan umum pemesinan CNC & 3,88 & 4,25 & 91,29 & $\begin{array}{c}\text { Sangat } \\
\text { Relevan }\end{array}$ \\
\hline keterampilan pemesinan bubut CNC & 3,72 & 3,44 & 108,14 & $\begin{array}{c}\text { Sangat } \\
\text { Relevan }\end{array}$ \\
\hline keterampilan pemesinan freis CNC & 3,93 & 4,29 & 91,61 & $\begin{array}{c}\text { Sangat } \\
\text { Relevan }\end{array}$ \\
\hline
\end{tabular}

Dari tabulasi perbandingan score untuk setiap $\mathrm{KI} / \mathrm{KD}$ menghasilkan bahwa secara keseluruhan pembelajaran pada kelompok kompetensi pengetahuan umum CNC baik di SMK maupun LPTK menunjukkan kategori 'sangat relevan'. Adapun rata-rata tingkat kesesuaian antara SMK dan industri mencapai 86,37\%, sedangkan untuk LPTK terhadap SMK mencapai 95,19\%. Untuk kelompok kompetensi pengetahuan tentang mesin bubut CNC, baik di SMK maupun LPTK menunjukkan kategori 'sangat relevan'. Adapun rata-rata tingkat kesesuaian antara SMK dan industri mencapai 91,40\%, sedangkan untuk LPTK terhadap SMK mencapai 106,99\%. Untuk kelompok kompetensi pengetahuan tentang mesin freis, baik di SMK maupun LPTK menunjukkan kategori 'sangat relevan'. Adapun rata-rata tingkat kesesuaian antara SMK dan industri mencapai $88,06 \%$, sedangkan untuk LPTK terhadap SMK mencapai $101,28 \%$. Hal ini juga menunjukkan bahwa pada perhatian pembelajaran di LPTK untuk kelompok KD ini melebihi ekspektasi SMK. 
Tabel 4. Relevansi KI/KD Pembelajaran LPTK dengan SMK

\begin{tabular}{lcccc}
\hline \multicolumn{1}{c}{ Kelompok Kompetensi } & $\begin{array}{c}\text { Skor Rerata } \\
\text { LPTK }\end{array}$ & $\begin{array}{c}\text { Skor Rerata } \\
\text { SMK }\end{array}$ & $\%$ & Kategori \\
\hline pengetahuan umum mengenai CNC & 3,56 & 3,74 & 95,19 & $\begin{array}{c}\text { Sangat } \\
\text { Relevan }\end{array}$ \\
\hline $\begin{array}{l}\text { pengetahuan tentang mesin bubut } \\
\text { CNC }\end{array}$ & 3,98 & 3,72 & 106,99 & $\begin{array}{c}\text { Sangat } \\
\text { Relevan }\end{array}$ \\
\hline $\begin{array}{l}\text { pengetahuan tentang mesin freis } \\
\text { CNC }\end{array}$ & 3,96 & 3,91 & 101,28 & $\begin{array}{c}\text { Sangat } \\
\text { Relevan }\end{array}$ \\
\hline keterampilan umum pemesinan CNC & 3,75 & 3,88 & 96,65 & $\begin{array}{c}\text { Sangat } \\
\text { Relevan }\end{array}$ \\
\hline keterampilan pemesinan bubut CNC & 4,04 & 3,72 & 108,60 & $\begin{array}{c}\text { Sangat } \\
\text { Relevan }\end{array}$ \\
\hline keterampilan pemesinan freis CNC & 3,82 & 3,93 & 97,73 & $\begin{array}{c}\text { Sangat } \\
\text { Relevan }\end{array}$ \\
\hline
\end{tabular}

Untuk kelompok kompetensi keterampilan umum pemesinan CNC, baik di SMK maupun LPTK menunjukkan kategori 'sangat relevan'. Adapun rata-rata tingkat kesesuaian antara SMK dan industri mencapai 91,29\%, sedangkan untuk LPTK terhadap SMK mencapai 96,65\%. Untuk kelompok kompetensi keterampilan umum pemesinan bubut CNC, baik di SMK maupun LPTK menunjukkan kategori 'sangat relevan'. Adapun rata-rata tingkat kesesuaian antara SMK dan industri mencapai 108,14\%, sedangkan untuk LPTK terhadap SMK mencapai 108,60\%. Sedangkan untuk kelompok kompetensi keterampilan umum pemesinan freis CNC, baik di SMK maupun LPTK juga menunjukkan kategori 'sangat relevan'. Adapun rata-rata tingkat kesesuaian antara SMK dan industri mencapai 91,61\%, sedangkan untuk LPTK terhadap SMK mencapai 97,73\%.

\section{Pembahasan}

Dari hasil elaborasi informasi informan menunjukkan bahwa kunci link-and-match bidang pemesinan $\mathrm{CNC} / \mathrm{CAM}$ terletak pada $\mathrm{KI} / \mathrm{KD}$, bukan pada mesin, controller, maupun jenis software yang dipergunakan dalam pembelajaran. Studi ini juga menunjukkan bahwa Kl/KD pembelajaran sudah mencakup berbagai aspek, baik dari segi pengetahuan maupun praktek. Hal ini menunjukkan bahwa pembelajaran CNC/CAM di LPTK maupun SMK sudah cukup memadai ditinjau dari kebutuhan pembelajaran CNC/CAM untuk mewujudkan output pembelajaran yang diperlukan [16]. Namun demikian, masih perlu diperdalam lagi apakah cara pandang tersebut, khususnya dari pihak lembaga pendidikan, disebabkan keterbatasan ataukah memang secara ideal seperti itu. Jika daya dukung memungkinkan, optimasi pemilihan software CAM dapat dipertimbangkan agar efektifitas pembelajaran semakin meningkat karena banyak penulis yang menyarankan berbagai metode untuk memilih software CAM yang optimal untuk pendidikan [17]-[19]. Prosser [20], dalam 16 dalil pendidikan kejuruan, menyebutkan bahwa pendidikan kejuruan akan efektif jika pembelajaran dilaksanakan dalam replika lingkungan kerja dimana lulusan akan bekerja, diberikan pelatihan dengan tugas dan peralatan yang sama dengan yang dipakai di lingkungan kerja, siswa dibiasakan berpikir dan bekerja sebagaimana diperlukan dalam dunia kerjanya. Dalam kasus kompetensi CNC/CAM, kesamaan tugas dan peralatan tersebut tidak mengacu pada kesamaan merk mesin, controller, dan perangkat lunak CAM yang dipergunakan, melainkan pada KI/KD yang merupakan representasi dari tugas dan permasalahan pekerjaan riil.

Data penelitian yang mengkonfirmasi kesesuaian $\mathrm{KI} / \mathrm{KD}$ pembelajaran $\mathrm{CNC} / \mathrm{CAM}$ di LPTK dan SMK menjadi bukti bahwa pembelajaran dalam bidang pemesinan CNC/CAM di lembaga pendidikan sudah sesuai dengan kebutuhan industri. Hal ini memenuhi prasyarat terwujudnya link-and-match antara dunia pendidikan dan industri yang harus dilakukan dengan melacak kesesuaian kompetensi dasar pembelajaran dengan standard operational procedures (SOP) di industri sebagaimana yang disampaikan oleh Surono [21]. Hal ini memberikan kemungkinan yang tinggi bagi lulusan SMK teknik pemesinan untuk siap memasuki dunia kerja karena kemungkinan defisit kompetensi sebagaimana yang dikhawatirkan oleh Marin [22]. Dengan demikian, studi ini cukup memberikan percaya diri bagi pelaku pendidikan, baik di SMK maupun LPTK, bahwa substansi pembelajaran yang dilaksanakan memiliki relevansi yang tinggi dengan kebutuhan dunia industri terkini. Di negara dengan sistem ketenagakerjaan yang sudah mapan seperti Perancis, Jerman, dan Amerika, tingkat relevansi pembelajaran ini berdampak pada penghargaan karyawan, semakin relevan pengalaman belajar dengan kebutuhan dunia kerja maka semakin tinggi penghargaan terhadap kinerja dan sebaliknya [23]. 
Temuan fakta bahwa keterpakaian $\mathrm{KI} / \mathrm{KD}$ tertentu lebih dari $\mathrm{KI} / \mathrm{KD}$ yang lain di industri hendaknya juga perlu menjadi perhatian bagi lembaga pendidikan untuk mengevaluasi agar pembobotan pembelajaran pada $\mathrm{KI} / \mathrm{KD}$ tersebut mendapatkan alokasi yang lebih agar relevansi pembelajaran makin dapat ditingkatkan. Namun, hal tersebut masih memerlukan kajian lebih lanjut khususnya pada sisi industri. Pada penelitian ini, informan berasal dari industri manufaktur dengan focus pada bidang mold and dies dan manufaktur komponen umum. Bisa jadi, karakteristik pekerjaan harian (daily task) yang secara mayoritas dikerjakan pada kedua industri tersebut berbeda sehingga kompetensi-kompetensi tertentu menjadi kurang dibutuhkan. Industri mold and dies cenderung kurang menggunakan kompetensi bubut, melainkan lebih didominasi pada kompetensi pemesinan freis. Industri manufaktur komponen umum bisa jadi cukup banyak membutuhkan kompetensi bubut dan jenis pabrikasi yang lain, dan kurang membutuhkan kompetensi freis. Hal ini disebabkan jenis produk yang dihasilkan membutuhkan proses produksi yang sesuai.

Hasil studi yang menunjukkan adanya relevansi antara pembelajaran di LPTK penghasil guru, SMK, dan industri terkait ini mengindikasikan bahwa link-and-match dalam hal keselarasan kompetensi sudah cukup terpenuhi. Konsep keselarasan dunia pendidikan pada sisi supply tenaga kerja dan industri pada sisi demander tenaga kerja perlu dikembangkan pada seluruh bidang usaha. Pedoman yang dikembangkan pada projek "Applying the G20 Training Strategy" dalam "Methodology for Demand-Driven Planning of VET Delivery" [24] bisa menjadi pedoman yang baik untuk mewujudkan hal tersebut. Jika keselarasan pada aspek kompetensi tenaga kerja ini sudah terlaksana dengan baik, maka tingginya pengangguran sebagaimana yang dipublikasikan Biro Pusat Statistik [25] bisa jadi tidak disebabkan pada sisi pendidikan (supply). Berbagai aspek keselarasan yang disyaratkan oleh Slamet [2] perlu diperiksa kembali, yaitu aspek kuantitas, lokasi dan waktu. Bisa jadi memang angka kebutuhan tenaga kerjanya tidak match atau memang saat ini sudah tidak membutuhkan spesifikasi tenaga kerja tersebut. Dari aspek kualitas, jenjang kualifikasi tenaga kerja juga perlu dianalisis. Jenjang kualifikasi lulusan SMK adalah level-2 KKNI [26]. Sementara pada jalur vokasional, masih ada jenjang pendidikan Diploma dengan level KKNI lebih tinggi. Jenjang manakah yang diperlukan oleh industri juga masih memerlukan survey lebih lanjut karena ketidak-sesuaian pada aspek tersebut juga merupakan ketidak-sempurnaan konsepsi link-and-match.

\section{SIMPULAN DAN SARAN}

\section{A. Simpulan}

Berdasarkan uraian di atas dapat disimpulkan hal-hal sebagai berikut: (1) berbagai $\mathrm{KI} / \mathrm{KD}$ dalam bidang CNC sebagaimana yang diamanatkan dalam kurikulum 2013 SMK telah terlaksana dengan baik dalam pembelajaran di SMK dan LPTK Kejuruan Teknik Mesin; (2) tingkat keselarasan KI/KD bidang CNC/CAM antara LPTK Kejuruan, SMK, dan industri saat ini pada level sangat relevan yang bermakna bahwa KI/KD yang diajarkan di LPTK Kejuruan dan SMK Teknik Pemesinan telah dikonfirmasi sangat relevan dengan yang dibutuhkan dunia industri; dan (3) jenis mesin, controller, dan software CAM bukan lah suatu permasalahan dalam hal link-and-match pembelajaran $\mathrm{CNC} / \mathrm{CAM}$, akan tetapi, yang menjadi kunci keselarasan adalah $\mathrm{KI} / \mathrm{KD}$ pembelajaran. Selain itu, ditemukan juga fakta tambahan bahwa pembelajaran di SMK dan PTM cenderung secara merata dilaksanakan dengan frekuensi yang relatif sama sedangkan kebutuhan industri cenderung lebih bervariasi, ada yang lebih dominan pada kompetensi tertentu dan kurang dominan pada kompetensi yang lain.

\section{B. Saran}

Berdasarkan penelitian tersebut, untuk penelitian berikutnya, disarankan menggali lebih dalam apakah berbagai mesin, controller, dan software CAM dengan fitur yang beragam dapat memberikan nilai plus terhadap pembelajaran dalam mencapai $\mathrm{KI} / \mathrm{KD}$ yang ditetapkan. Hal ini untuk menghindari miss-judgement bahwa focus pembelajaran hanyalah $\mathrm{KI} / \mathrm{KD}$. Fasilitasi berbagai mesin, jenis controller, dan software CAM untuk mencapai KI/KD masih memerlukan studi lebih lanjut. Selain itu, Temuan bahwa ada $\mathrm{KI} / \mathrm{KD}$ tertentu yang cenderung lebih banyak dipergunakan perlu diperdalam kembali untuk memberikan justifikasi yang lebih cermat apakah $\mathrm{KI} / \mathrm{KD}$ yang kurang diperlukan di industri tersebut perlu dikurangi untuk memberikan porsi lebih bagi KI/KD yang lebih dominan pemakaiannya di industri. Kemungkinan link-and-match jenis industri manufaktur tertentu terhadap kesesuaian pembelajaran juga masih diperlukan untuk mempelajari perlunya dan level efektifitas kemitraan industri dengan SMK tertentu [27] dalam mengembangkan tenaga kerja. 


\section{UCAPAN TERIMAKASIH}

Penelitian ini didanai PNBP Universitas Sebelas Maret dengan nomor kontrak 452/UN27.21/PN/2020. Ucapan terima kasih kami sampaikan kepada semua pihak yang telah membantu terlaksananya penelitian ini, antara lain Lembaga Penelitian dan Pengabdian Kepada Masyarakat Universitas Sebelas Maret, SMK mitra dan guru responden penelitian, dosen pengampu CNC Prodi Pendidikan Teknik Mesin UNS, dan industri mitra yang di antaranya adalah PT. King Manufacture, PT. Meiwa Mold Indonesia, dan PT. Yogya Presisi Tehnikatama Industri.

\section{DAFTAR PUSTAKA}

[1] E. P. Disas, "Link and Match sebagai Kebijakan Pendidikan Kejuruan," J. Penelit. Pendidik., vol. 18, no. 2, pp. 231-242, 2018.

[2] P. Slamet, "Kebijakan Pendidikan Kejuruan: Refleksi Kritis dan Koreksi," 2014.

[3] S. Billett, "Defining the Demand Side of Vocational Education and Training: Industry, Enterprises, Individuals and Regions," J. Vocat. Educ. Train., vol. 52, no. 1, pp. 5-31, 2000 doi: $10.1080 / 13636820000200104$.

[4] the Republic of Indonesia, "Undang-Undang No 20/2003 tentang Sistem Pendidikan Nasional." President Republic of Indonesia, Jakarta, 2003.

[5] S. S. Feshina, O. V. Konovalova, and N. G. Sinyavsky, "Industry 4.0-transition to new economic reality," in Studies in Systems, Decision and Control, vol. 169, 2019.

[6] C. B. Frey and M. A. Osborne, "The Future of Employment: How Susceptable are Jobs to Computerisation?," Russian Metallurgy (Metally), vol. 2002. Oxford University, Oxford, 2013.

[7] C. Klingenberg, "Industry 4 .0: what makes it a revolution?," Pap. Present. EurOMA 2017, no. July, pp. 1-10, 2017, doi: 10.1016/j.promfg.2018.02.034.

[8] M. B. Triyono, "Tantangan Revolusi Industri ke 4 (i4.o) bagi Pendidikan Vokasi," in Seminar Nasional Vokasi dan Teknologi (Semnasvoktek), 2017, pp. 1-5.

[9] B. Canis, "Electrification May Disrupt the Automotive Supply Chain," Congressional Research Service, 2019. [Online]. Available: https://fas.org/sgp/crs/misc/IF11101.pdf.

[10] G. M. Martinov, A. B. Ljubimov, and L. I. Martinova, "From classic CNC systems to cloud-based technology and back," Robot. Comput. Integr. Manuf., vol. 63, 2020, doi: 10.1016/j.rcim.2019.101927.

[11] E. J. Van Holm, "The Future of Jobs 2018," Switzerland, 2017.

[12] N. E. Sohimi, H. M. Affandi, M. S. Rasul, R. M. Yasin, N. Nordin, and S. Adam, "Malaysian industrial collaborations for skills development in 4th industrial revolution," J. Tech. Educ. Train., vol. 11, no. 3, pp. 63-72, 2019, doi: 10.30880/jtet.2019.11.03.009.

[13] DGoSE, "Peraturan Direktorat Jenderal Pendidikan Dasar dan Menengah Kementerian Pendidikan dan Kebudayaan No 464/D.D5/KR/2018 tentang Kompetensi Inti dan Kompetensi Dasar Mata Pelajaran Muatan Nasional, Muatan Kewilayahan, Dasar Bidang Keahlian, Dasar Program Kea." Direktur Jenderal Pendidikan Dasar dan Menengah, Jakarta, 2018.

[14] J. W. Creswell, Educational Research: Planning, Conducting, and Evaluating Quantitative and Qualitative Research, 2nd ed. Boston: Pearson, 2005.

[15] Purwanto, Evaluasi Hasil Belajar. Yogyakarta: Pustaka Pelajar, 2010.

[16] X. Li, "Curriculum reform and practice of mechanical CAD/CAM technologys," Int. J. Emerg. Technol. Learn., vol. 13, no. 8, 2018, doi: 10.3991/ijet.v13i08.9040.

[17] M. Abouelala, M. T. Janan, and P. Brandt-Pomares, "Methodology of selecting CAM software package for education based on a questionnaire," Int. J. Mech. Eng. Educ., vol. 43, no. 2, 2015, doi: $10.1177 / 0306419015588397$.

[18] M. Abouelala, P. Brandt-Pomares, and M. Taha Janan, "CAM Software Selection Criteria in Education Based on Activity Theory," Int. J. Appl. Eng. Res. ISSN, vol. 11, no. 20, 2016.

[19] Z. Ayağ, "An approach to evaluate CAM software alternatives," Int. J. Comput. Integr. Manuf., vol. 33, no. 5, 2020, doi: 10.1080/0951192X.2020.1757156.

[20] C. A. Prosser and T. A. Ouigley, Vocational Education in a Democracy. Chicago: American Technical Society, 1950.

[21] Surono, Z. Syahrial, and B. Wibawa, "Model of interface between curriculum, competence standard, and standards operational procedure to ensure their link and match," Int. J. Adv. Sci. Technol., vol. 29, no. 4 Special Issue, 2020.

[22] A. Marin and S. Hayes, "The occupational context of mismatch: Measuring the link between occupations and areas of study to better understand job -worker match," Can. J. Sociol., vol. 42, no. 1, 2017, doi: $10.29173 /$ cjs 19415.

[23] T. Bol, C. Ciocca Eller, H. G. van de Werfhorst, and T. A. DiPrete, "School-to-Work Linkages, 
Educational Mismatches, and Labor Market Outcomes," Am. Sociol. Rev., vol. 84, no. 2, 2019, doi: $10.1177 / 0003122419836081$.

[24] V. Gasskov, "Methodology for Demand-Driven Planning of VET Delivery," 20180620, 2018.

[25] Central Bureau of Statistics, "Berita Resmi Statistik, 5 Mei 2020." Badan Pusat Statistik Indonesia, 2020.

[26] Republic of Indonesia, "Peraturan Presiden Republik Indonesia No 8/2012 tentang Kerangka Kualifikasi Nasional Indonesia." President Republic of Indonesia, Jakarta, 2012.

[27] J. J. Watters, H. K. Pillay, and M. Flynn, "Industry-School Partnerships: A strategy to enhance education and training opportunities," Queensland, 2016. 